\title{
New Composite Materials Based on NiTi
}

Pavel Novák, Eva Kristianová, Milan Valalik, Clarisse Darme, Pavel Salvetr

University of Chemistry and Technology, Prague, Department of Metals and Corrosion Engineering, Technická 5, 166 28 Prague 6, Czech Republic, E-mail: panovak@ vscht.cz

NiTi alloy is characterized by many interesting properties assiciated with the shape memory behaviour. Since this material can be superelastic and recover the shape after deformation, it can be considered as potential matrix for composites. In this work, the possibility of preparation of NiTi matrix composites was tested. Two kinds of materials were studied - NiTi matrix composite reinforced by ceramic particles and in-situ composite containing NiTi and hard $\mathrm{Ti}_{2} \mathrm{Ni}$ phase obtained by reactive sintering of $\mathrm{Ni}+\mathrm{Ti}$ mixture.

Keywords: NiTi, powder metallurgy, composite

\section{Acknowledgement}

This research was financially supported by the Czech Science Foundation, project No. 14-03044S.

\section{References}

[1] VOJTĚCH, D., KUBÁSEK, J., NOVÁK, P. (2013). Corrosion properties of the superelastic shape memory Ni-Ti alloy for medical implants. In: Manufacturing Technology, Vol. 13, No. 3, pp. 409-414. UJEP. Czech Republic.

[2] FARVIZI, M., EBADZADEH, T., VAEZI, M.R., YOON, E.Y., KIM, Y-J., KIM, H.S., SIMCHI, A. (2014). Microstructural characterization of HIP consolidated NiTi-nano $\mathrm{Al}_{2} \mathrm{O}_{3}$ composites. In: Journal of Alloys and Compounds, Vol. 606, pp. 21-26.

[3] HU, L., KOTHALKAR, A., PROUST, G., KARAMAN, I., RADOVIC, M. (2014). Fabrication and characterization of $\mathrm{NiTi} / \mathrm{Ti}_{3} \mathrm{SiC}_{2}$ and $\mathrm{NiTi} / \mathrm{Ti}_{2} \mathrm{AlC}$ composites. In: Journal of Alloys and Compounds, Vol. 610, pp. 635644. Elserier. Netherlands.

[4] NOVÁK P., ŠKOLÁKOVÁ A., VOJTĚCH V., KNAISLOVÁ A., POKORNÝ P., MORAVEC H., KOPEČEK J., KARLÍK M., KUBATÍK T.F. (2014). Application of Microscopy and X-ray Diffraction in Optimization of the Production of NiTi Alloy by Powder Metallurgy. In: Manufacturing Technology, Vol. 14, pp. 387-392.

[5] NOVÁK, P., MORAVEC, H., SALVETR, P., PRŮŠA, F., DRAHOKOUPIL, J., KOPEČEK, J., KARLÍK, M., KUBATÍK, T.F. (2015). Preparation of nitinol by non-conventional powder metallurgy techniques, In: Materials Science and Technology, DOI: http://dx.doi.org/10.1179/1743284715Y.0000000041

[6] NOVÁK, P., VODĚROVÁ, M., HENDRYCH, R., KUBATÍK, T., MICHALCOVÁ, A., VOJTĚCH, D. (2013). Preparation of aluminium-based quasicrystals. In: Manufacturing Technology, Vol. 13, No. 3, pp. 390-394. UJEP. Czech Republic.

[7] NOVÁK, P., VOJTĚCH, D., ŠERÁK, J. (2006). Wear and corrosion resistance of a plasma-nitrided PM tool steel alloyed with niobium. In: Surface and Coatings Technology, Vol. 200, pp. 5229 - 5236. Elsevier. Netherlands. 